\title{
Sexual dimorphism and natural movements of the American eel (Anguilla rostrata) in Rhode Island streams and estuaries
}

\author{
H. E. WinN, W. A. Richkus \& L. K. WinN \\ Graduate School of Oceanography, University of Rhode Island; \\ Kingston, Rbode Island, USA
}

\begin{abstract}
KURZFASSUNG: Geschlechtsdemorphismus und Wanderaktivität des Amerikanischen Aales (Anguilla rostrata) in Fließgewässern und Flußmündungen von Rhode Island. Der Augendurchmesser männlicher Amerikanischer Blankaale (Anguilla rostrata) war beträchtlich größer als derjenige von Amerikanischen Gelbaalen. Blankaalmännchen hatten eine wesentlich geringere Durchschnittslänge als Blankaalweibchen. In kleinen Fließgewässern dominierten die Männchen, in Flußmündungen war der Weibchenanteil vergleichsweise größer. Die Abwanderung ins Meer fand hauptsächlich während der Monate September bis November statt und war verstärkt bei nennenswerten Regenfällen sowie während des dritten und vierten Mondviertels. Die Untersuchungen erbrachten in vieler Hinsicht ähnliche Ergebnisse, wie sie vom Europäischen Aal bekannt sind. Es wird angenommen, daß hinsichtlich der Stimuli für Beginn und Aufrechterhaltung der Laichwanderung eine große Zahl von funktionellen Sicherungen vorhanden ist, welche die Vermehrung gewährleisten.
\end{abstract}

\section{INTRODUCTION}

It is well known that the migration of the adult European eel (Anguilla anguilla) occurs around the dark of the moon and that the migratory forms have enlarged eyes (Bertin, 1956; Deelder, 1970). Until recently, data on the European species has been applied without substantiation to the American eel (Bigelow \& WeLSH, 1925; HILDEBRAND \& SCHROEDER, 1928).

The life history of the American eel (Anguilla rostrata) is less well documented. It is well known by fishermen that at least females run near the dark of the moon (EALEs, 1968). Much less is known about the male due to the fact that the mesh size of commercial traps is not small enough to contain them. Some data have been given on the effects of rain and lunar phase (SMITH \& SAUNDERS, 1955). Recently, enlargement of the eye has been demonstrated (VLADYKov, 1973; WENner \& Musick, 1974), and VLADYKov (1966) has made statements about the distribution of sexes in various environments.

This paper presents data based on fyke net and fishway trap catches from 1967 
to 1972 in relation to environmental variables. Eye size and distribution of sexes in freshwater streams and estuaries are shown. The catches for 1967-1968 were presented earlier (WINN \& HAMMEN, 1969).

\section{MATERIALS AND METHODS}

The horizontal and vertical diameter of the eye was measured in the usual way (Boetius \& Boetius, 1967). The sum of the two diameters was divided by two, and plotted against length. Ninety-nine individuals from all 1969 collecting stations and 85 collected on one day, November 9, 1972, at Station 10, were measured.

Externally, silver eels were recognized by their coloration: almost black backs and pectoral fins, bronze stripe along their sides, and silver bellies. In some cases the bellies were blotched.

The sex of silver eels was determined by gross examination of the enlarged gonads and in some cases by size alone.

Eels were captured by fyke nets with $18 \mathrm{~mm}$ mesh or smaller, and with wings of various lengths. In very small streams, the whole brook would be traversed, whereas 3 to $15 \mathrm{~m}$ wings only partially covered areas in the estuaries. Various $\mathrm{tr}$ a $\mathrm{p} \mathrm{loc} \mathrm{a}-$ $t$ i o $\mathrm{s}$ were as follows: Station 1: entrance of cove entering Ninigret Pond, immediately west of Charlestown Naval Air Station (brackish); Station 2: off Charlestown Beach road above the bridge where Green Hill Pond enters Ninigret Pond (brackish, two traps); Station 3: exit of small pond on northernmost edge of Green Hill Pond (freshwater); Station 4: exit of small stream immediately to west of above station (freshwater); Station 6: in Saugatucket River above Peace Dale Mill and in canal by the mill (freshwater); Station 8: Pettaquamscutt River just below Middle Bridge on east side (brackish); Station 8A: Pettaquamscutt R. opposite southern end of Riverside Drive (brackish); Station 9: in stream about $100 \mathrm{~m}$ below the Gilbert Stuart fishway (freshwater); Station 10: fishway of Annaquatucket R. on Route 1A. Exit of Hamilton Reservoir (freshwater); Station 10A: Annaquatucket $R$. just below fishway on Route 1A (freshwater); Station 11: near exit of Bissel Cove (Annaquatucket R.) into Narragansett Bay (brackish).

In 1971, at Station 10, hourly counts were made of downstream passages with a Smith-Root Model 602 Electronic Fish Counter. The system was described by Richkus (1975). In 1969, eels were caught with a fyke net attached to the counter. In 1970, 1971, and 1972, eels were captured by a modified Wolf-type trap (Rrchkus, 1974). The traps were primarily designed to catch juvenile alewives (Alosa pseudoharengus).

\section{RESULTS}

The relationship of eye size (vertical plus horizontal diameters divided by 2) is plotted against length in Figures 1 and 2. The eels measured in Figure 1 were caught at various stations throughout the fall of 1969, and those for Figure 2 were caught the same day (see "Materials and Methods"). Silver males had an average diameter of 
$6.4 \mathrm{~mm}$ in Figure 1 and $5.5 \mathrm{~mm}$ in Figure 2. Yellow male-sized individuals in Figure 1 averaged $4.1 \mathrm{~mm}$. Female-sized yellows in Figure 1 averaged $5.21 \mathrm{~mm}$, silver females in Figure 1, $6.89 \mathrm{~mm}$, and silver females in Figure 2,6.8 $\mathrm{mm}$. The eyes of the silver males were larger than those of comparably sized yellow eels and almost as large as

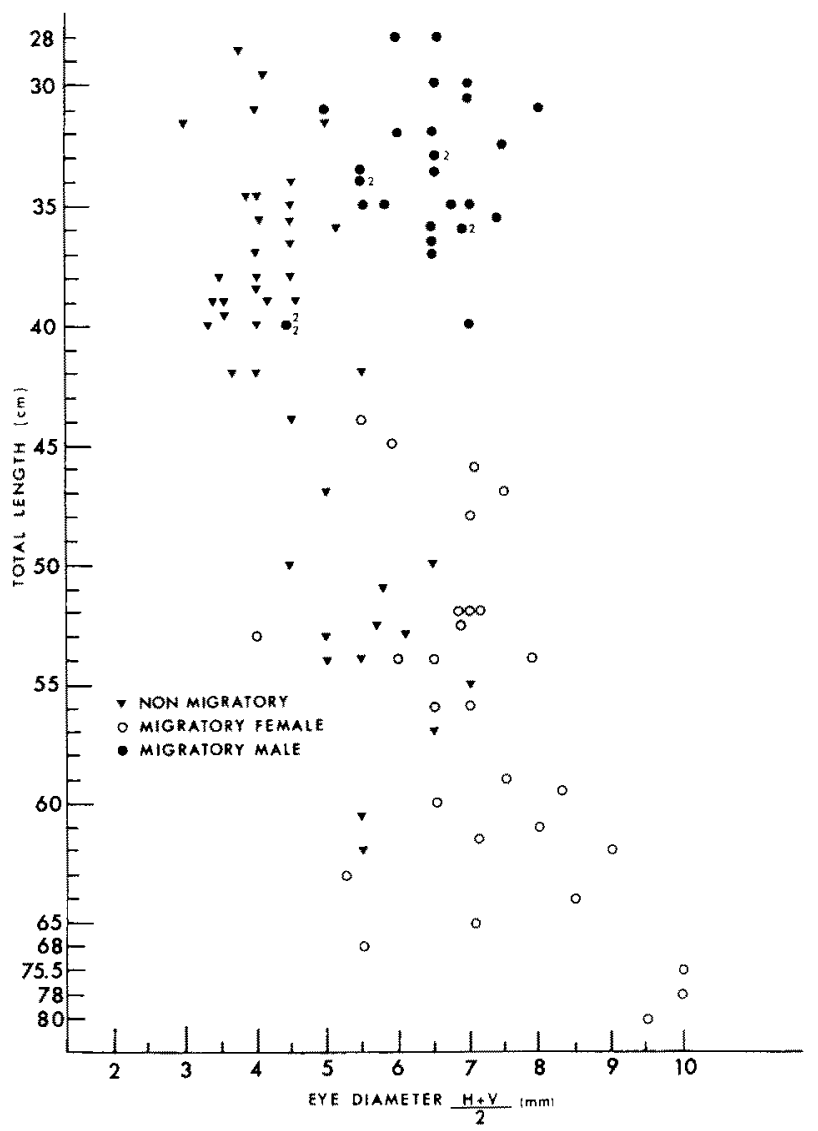

Fig. 1: Eye diameter of Anguilla rostrata (horizontal plus vertical divided by 2) plotted against total length of a series of eels caught at various stations in the fall of 1969

the eye of silver females. The data were inadequate to determine whether or not the silver females had slightly larger eyes than comparably sized yellow eels. On an absolute basis, large yellow non-migratory eels had larger eyes than small yellow nonmigratory male-sized eels. There was less variation in the one day catch of Figure 2.

Migratory males varied in length from 28 to $40 \mathrm{~cm}$; however, those caught on the same day (Fig. 2) were on the average smaller than those of Figure 1. Females varied from 41 to $80 \mathrm{~cm}$.

In Table 1 the distribution of sexes in various catches is given. All freshwater 
stations had a high percentage of males. Except for Station 8, there were fewer males caught in the brackish water stations.

Figure 3 shows that over a 15 month period, most eels were caught in September, October and November. This data includes both silver and yellow eels. There were 169 silver eels caught only in the months of September through December (only 5 in December), and of the 100 yellow eels caught, 72 were obtained from September through December (only 3 in December).

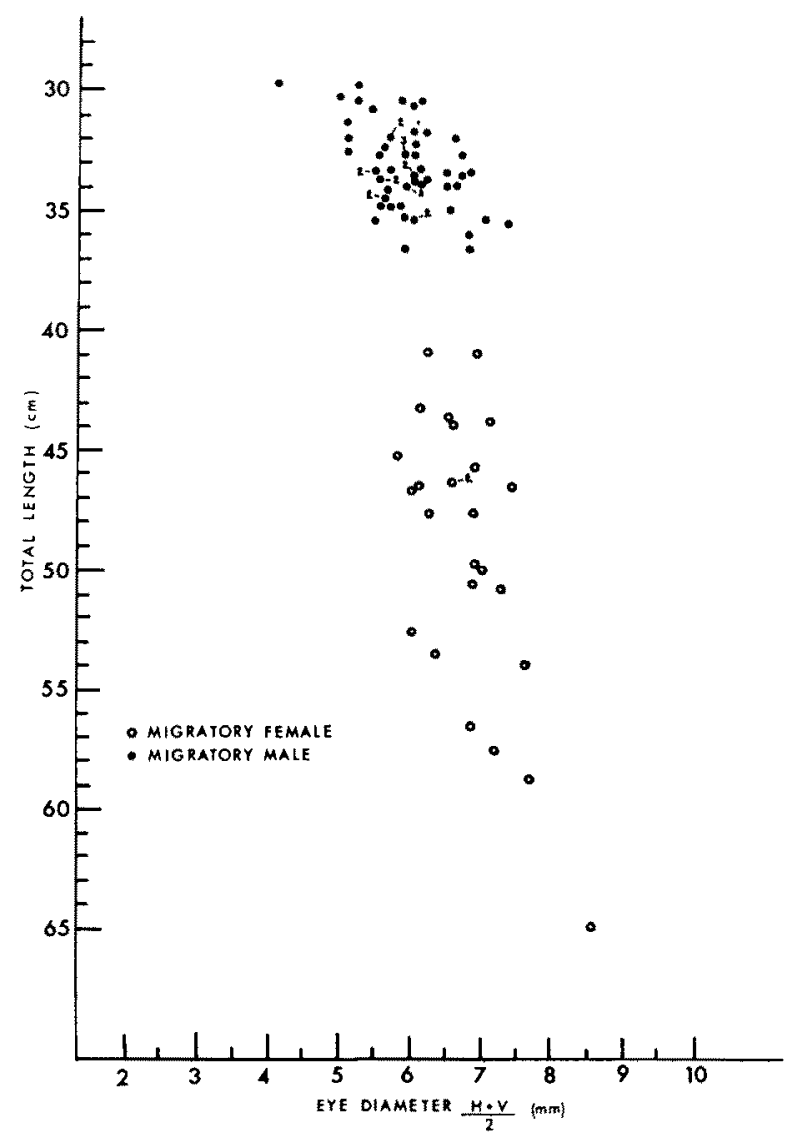

Fig. 2: Similar to Figure 1 but based on a one day collection at Station 10 on November 9,1972

In Figures 4, 5 and 6, catches were related to rainfall and lunar period. It is obvious that runs occur after heavy rains. It is less obvious that there are larger runs between the full and new moon. Only a few times were there significant runs without rain. One was in a 7 day period around September 22 in Figure 4; another in the 3 day period of October 19 to 22,1970 in Figure 5; October 25 to 28, 1972 in Figure 5; and November 11, 1970, shown clearly in Figure 7. All occurred between the full and new moon. One small run occurred in August, 1971 (Fig. 5). 
Table 1

Anguilla rostrata. Sex ratios at various stations (see "Materials and Methods"). Stations where less than 9 were caught were not included and not all catches at Station 10 were included

\begin{tabular}{|cllrrr|}
\hline Station & $\begin{array}{c}\text { Year or } \\
\text { date }\end{array}$ & $\begin{array}{c}\text { Fresh or } \\
\text { brackish water }\end{array}$ & Males & Females & $\begin{array}{c}\text { Percent of } \\
\text { males }\end{array}$ \\
\hline 2 & 1967 & brackish & 6 & 10 & 38 \\
8 & 1967 & brackish & 11 & 4 & 74 \\
9 & 1967 & fresh & 12 & 3 & 80 \\
11 & 1967 & brackish & 4 & 5 & 44 \\
$6,6 \mathrm{~A}$ & 1967 & fresh & 18 & 4 & 67 \\
2 & 1968 & brackish & 18 & 19 & 49 \\
3 & 1968 & fresh & 19 & 0 & 100 \\
8 & 1968 & brackish & 13 & 2 & 87 \\
8 & 1969 & brackish & 6 & 8 & 43 \\
9 & 1969 & fresh & 30 & 0 & 100 \\
10 & 1972 & fresh & & & \\
& October 8 & & 418 & 22 & 95 \\
& October 10 & & 90 & 1 & 99 \\
& October 17 & & 17 & 6 & 74 \\
& October 26 & & 20 & 6 & 77 \\
& October 27 & & 11 & 8 & 58 \\
& October 29 & & 438 & 74 & 86 \\
& October 30 & & 173 & 43 & 80 \\
& Total Station 10 & & 1167 & 160 & 88 \\
\hline
\end{tabular}

Runs occurred between the beginning of the $1800 \mathrm{~h}$ and the end of the $2300 \mathrm{~h}$ (Figs 6 and 7). Counts were 295 between the beginning of 1800 and end of $2300 \mathrm{~h}$, and all other hours, 14, on November $7 ; 43$ vs. 6 on November $11 ; 83$ vs. 12 on November 13; and 81 vs. 8 on November 15. Two of the days are not shown in the figures. The actual catches were usually less than the counts but were always correlated.

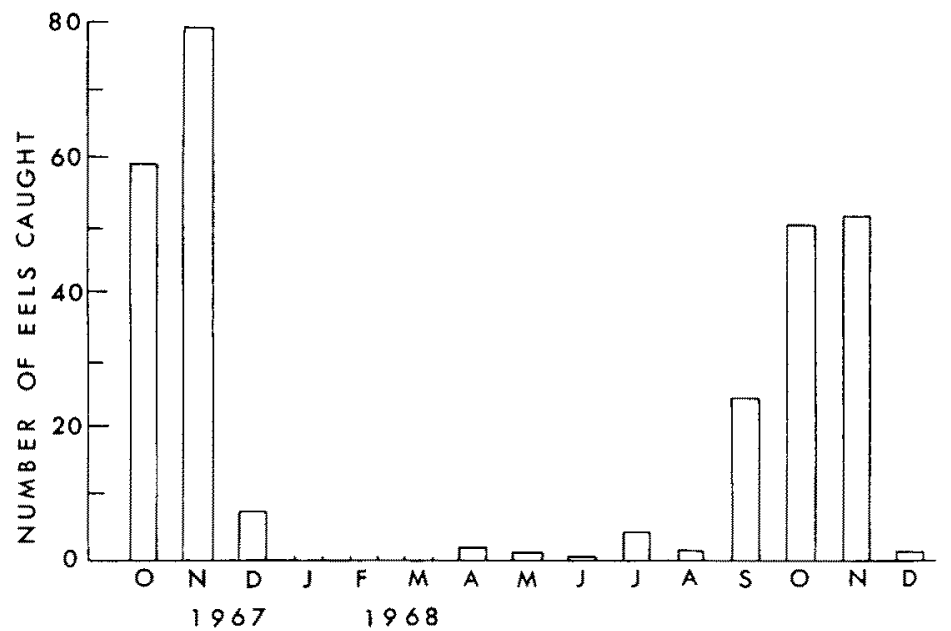

Fig. 3: Catches of eels per month in various passive fyke net traps set over a 15 month period. These were caught at Stations 1, 2, 3, 6, 8, 8A, 9, 10A, and 11 


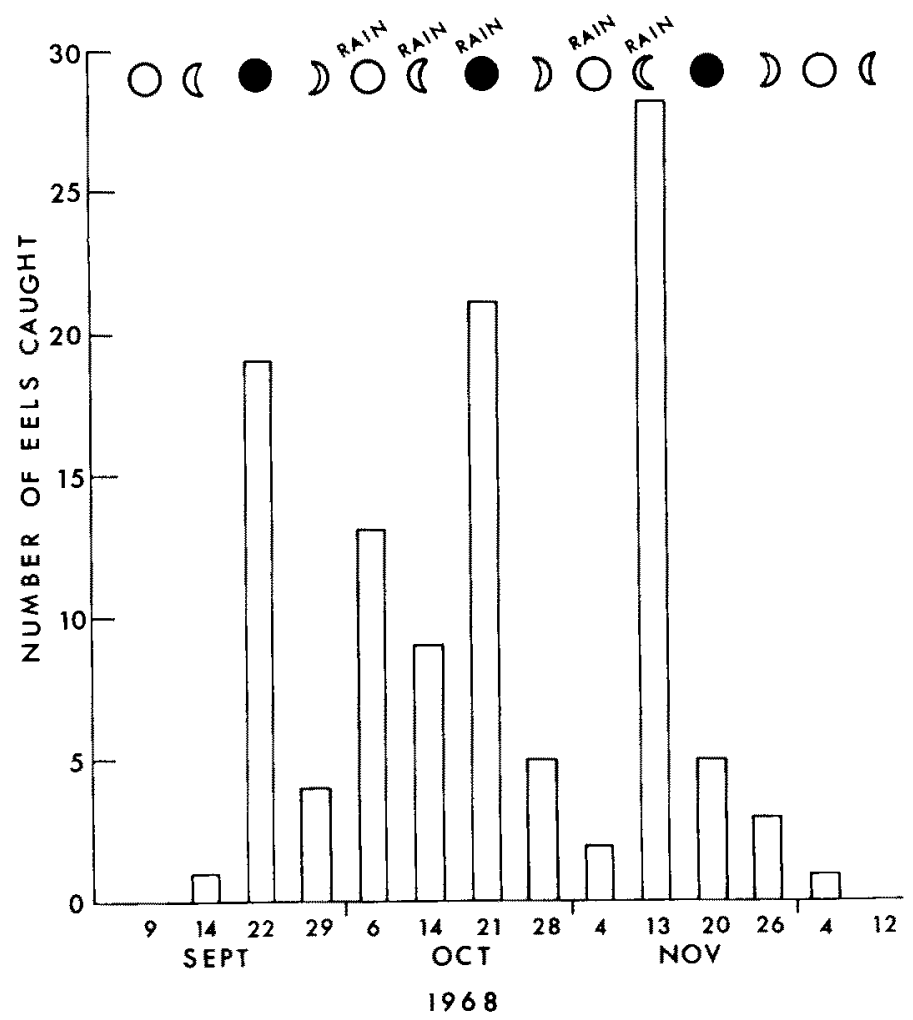

Fig. 4: Number of eels caught in relation to the lunar period and rainfall for 1968. Each bar represents seven days of catch; the date is the center of the 7 day period. These were caught at Stations $2,3,4,6,8$, and 9

\section{DISCUSSION}

Only recently has it been shown that the eye of the American eel enlarges. VLADYKov (1973) measured the enlarged eyes of three museum specimens, at least two of which were males. WENNER \& MUSICK (1974) demonstrated that silver males had larger eyes relative to gape length than females and that silver female eyes were slightly larger than yellow eel eyes. The yellow eel sample was not comparable to the silver female sample in average total length, which might make a difference if there was some allometric increase in eye size with length, as shown in Figures 1 and 2. The eyes of silver males were much larger than comparably-sized yellows and essentially the same size as larger yellow and silver females in our sample (Figs. 1 and 2). The largest of silver females appeared to have larger eyes than smaller females and males. Our sample is inadequate to determine differences in eye size between female-sized yellow and silver eels. The greater increase in eye size of the American male eel, as it adds its migratory livery, and leaves the rivers and estuaries, is comparable to the 


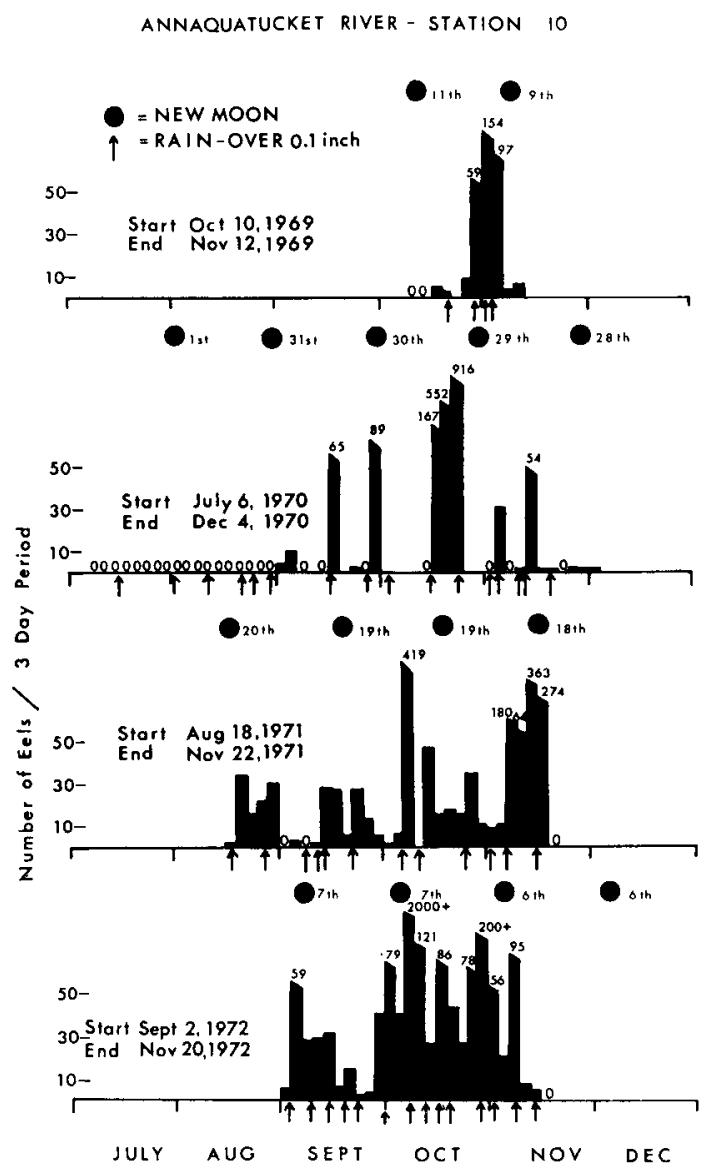

Fig. 5: Catches for three day periods in the Hamilton fishway of Annaquatucket River (Station 10) for four years. If there was a fourth day at the end of a month it was included in the last 3 day period of the month. Starting and ending dates are given along with periods of over 0.1 inches $(2.5 \mathrm{~mm})$ of rain. Zeros indicate no catch; dates without a zero or a catch are times the trap was not operating

European eel condition (DEELDER, 1970; TESCH, 1973). In several studies, it was shown that in changing into the silver phase, the male eye increases greatly, and the female eye may increase slightly (Bö̈тIUS et al., 1962; Bö̈тIUs \& Bö̈TIUS, 1967). CARLISLE \& Denton (1959) said that the enlarged eye can gather more light. We interpret the increased eye size of the male as an adaptation to gathering dim light in a comparable manner to females on their oceanic migration. It has also been suggested that the increase in eye size is degenerative rather than functional (BERTIN, 1956). Whether female eyes typically enlarge significantly in the seaward phase of the migration is an open question. Several females, caught at sea, had unusually enlarged eyes (SvärDSON, 1949; RAsmussen, 1951).

The sexual dimorphism of size in our samples is quite similar to that of the 


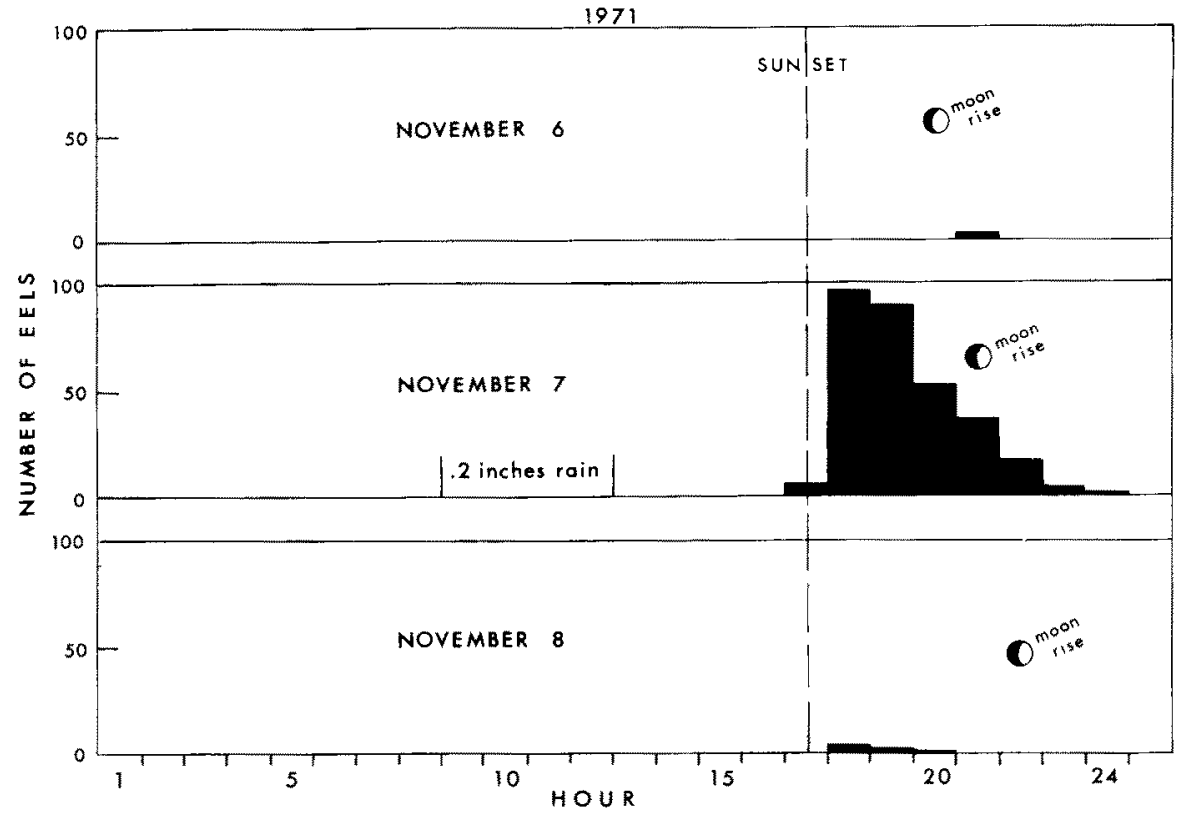

Fig. 6: Hourly counts on the electronic counter for 3 days in the fishway of Annaquatucket River (Station 10) in 1971. Lunar phase is shown

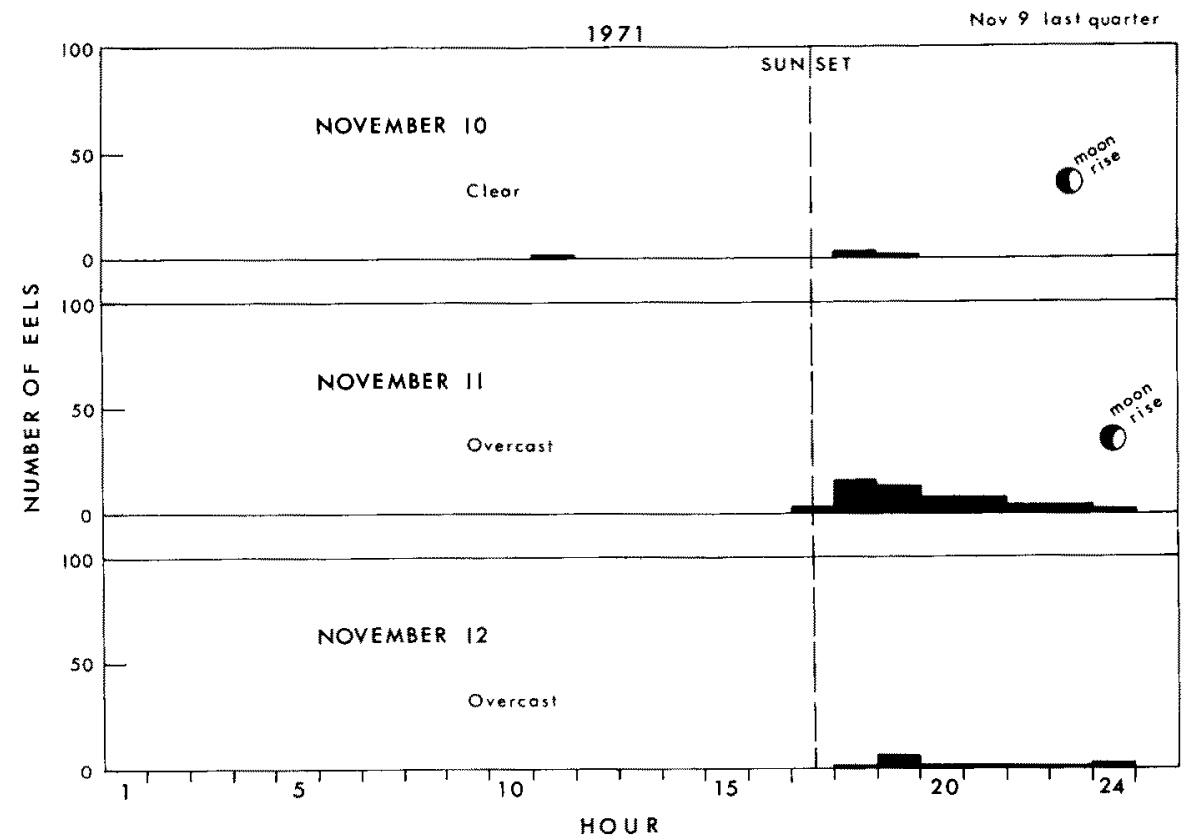

Fig. 7: Hourly counts on the electronic counter for 3 days in the fishway of Annaquatucket River (Station 10) in 1971. Lunar phase is shown 
European eel (see summaries in DEELDER, 1970; TESCH, 1973) and to reports on the American eel (WENNER \& Musick, 1974; VlaDYKov, 1973). The males were somewhat smaller on the average in our samples than for some other studies (DEELDER, 1970).

In Europe, males occur in estuaries and females in large rivers, although there is some variation (for summaries see Bertin, 1956; DeELder, 1970; TeSCH, 1973). In our area, males predominate in small freshwater streams. Catches of females increased in estuaries and it appears as if males caught in estuaries came from fresh water, because we know males are running out of fresh water at the same time. We suspect, but cannot adequately document, that females would increase in proportion to males in large river systems as is the case in Europe. Large, female yellow eels predominated in our estuarine collections. VLADYKOV's (1966) statements that females are found principally in fresh water and that the proportion of males increases to the south in North America must be discounted. A random sample cannot be demonstrated; nor were samples comparable, due to the complex distribution of sexes in estuaries and fresh water. The mesh size of commercial traps, which provided some of his data, is usually too large to contain males. Apparently, Smith \& Saunders (1955) had many males in their Canadian catches, based on the size of animals in the autumn downstream runs.

In our hourly eel counts, it was clear that most of the eels ran down the fish ladder just after sunset to $2300 \mathrm{hr}$. Similarly, European eels usually run at the same time (DeElder, 1970; LOWE, 1952; BrÄUtigam, 1961). This coincided with the moon rising later each day in the early hours of the third and fourth quarters, as HaIN (1975) has discussed.

The catches of Figure 3 were very small, which indicates that our traps were inefficient, even when we attempted to block the entire stream. Usually swollen streams destroyed the set, which was when we expected to catch the most eels. Our choice of trap positions, in the shallow estuaries, was completely controlled by boat traffic and we were unable to set them in places we considered desirable. In most cases, the depth of water at high tide was less than five feet.

More yellow eels were captured when silver eel captures increased, but in smaller numbers. This supports Hain's (1975) contention that even yellow eels exhibit the initial tendencies to migrate under the appropriate environmental conditions. He obtained negative rheotactic responses by both yellow and silver eels under certain conditions.

It has been well documented in Europe that eels run after rains and more often in the third and fourth lunar quarters (DEELDER, 1954; FROST, 1950; Lowe, 1952; see also summaries in TESCH, 1973 and DeELder, 1970). This is known for the American eel by fishermen (EALEs, 1968) and reported by SMITH \& Saunders (1955) for eels in the Maritime provinces of Canada. Our catches support these observations. Runs occurred after rains and during the third and fourth lunar quarters when rain is not a factor.

Some European studies (KNÖPP, 1952; summary in DeELDER, 1970) emphasize that multiple factors initiate migratory runs. The environmental effects of rain are multifaceted. Temperature changes, flow increases, turbidity increases, chemical composition of the water changes, and light is reduced. The relation of early evening movement to the absence of moonlight in the third and fourth quarter has suggested light as a causal 
factor in releasing the downstream movement. HaIN (1975) triggered movement by darkening tanks. Several authors (Bö̈тIUs, 1967; JENs, 1953) reported that light is not causal because a lunar related escapement was obtained in tanks darkened for several months. Thus, it would seem clear from HAIN's experiments that light is an exogenous control with an underlying endogenous component. If one were to have three months of complete cloud cover, theoretically, the eels would leave at the proper time due to an endogenous rhythm. Microseisms also have been implicated as a correlated factor (DEELDER, 1954). It cannot be ruled out that other stimuli resulting from rain might be releasing stimuli also (e.g. pressure, chemical changes). Thus the strategy would be a system in which a great deal of redundancy is built in so that no disastrous mistakes are made in the reproductive and final critical phase of their life cycle.

Acknowledgements. We are much indebted to the many persons who tended traps and made some of the measurements, such as P. Fenhacen, S. Hammen, S. Rebach, J. Schneider, B. Thunberg, J. Hain, R. Edel, M. Hyman, J. Fish, J. Mason, M. Fine, and R. Kenney. The research was originally supported by U.S.P.H.S. Grant NB06397-05 and ONR Contract N00014-68-A-0215-0003. Support for the counters and special traps on the Annaquatucket $R$. was supplied by the Rhode Island Division of Fish and Wildlife, Project reference nos. F26, R6 and 7, 11-5. J. HaIN and R. EDfl kindly criticized the manuscript. We thank Dr. Tesch for translating the abstract.

\section{SUMMARY}

1. The eyes of silver males were much enlarged, but not thoses of female Anguilla rostrata specimens.

2. Silver males were smaller than silver females.

3. Males predominated in freshwater and the proportion of females increased in estuaries.

4. In trap catches from 1969 to 1972 , most silver eel runs occurred from September through November and came after rains or in the third and fourth lunar quarters. More yellow eels are also caught at this time.

5. Based on records from an electronic fish counter, silver eels moved primarily from just after sundown to $2300 \mathrm{hr}$.

6. It is suggested that with regard to stimuli initiating migration, a great deal of redundancy is built into the system so that reproduction is assured.

\section{LITERATURE CITED}

Bertin, L., 1956. Eels. Cleaver-Hume, London, $192 \mathrm{pp}$.

Bigelow, H. B. \& Welsh, W. W., 1925. Fishes of the Gulf of Maine. Bull. U.S. Bur. Fish. 40 (1), 1-567.

Boet'uUs, I. \& Boërrus, J., 1967. Studies in the European eel, Anguilla anguilla (L.). Experimental induction of the male sexual cycle, its relation to temperature and other factors. Meddr. Danm. Fisk, -og Havunders. 4, 339-405.

Bö̈тrus, J., 1967. Experimental indication of lunar activity in European silver eels, Anguilla anguilla (L.). Meddr. Danm. Fisk. -og Havunders. 6, 1-6. 
- Boëtius, I., Hemmingsen, A. M., Bruun, A. F. \& Møller-Christensen, E., 1962. Studies of ovarial growth induced by hormone injections in the European and American eel ( $A n$ guilla anguilla L. and Anguilla rostrata LeSUEUR). Meddr. Danm. Fisk. -og Havunders. 3, $183-198$.

BRÄUtigam, R., 1961. Uber Versuche zur Intensivierung des Blankaalfanges durch die Kombination von Lichtsperren und Großreusen und ihre grundsätzlichen Bedingungen. Fisch.Forsch. 4, 19-25.

CARlisle, D. B. \& Denton, E. J., 1959. On the metamorphosis of the visual pigments of Anguilla anguilla (L.). J. mar. biol. Ass. U.K. 38, 97-102.

DeELDER, C. L., 1954. Factors affecting the migration of the silver eel in Dutch inland waters. J. Cons. perm. int. Explor. Mer. 20, 177-185.

- 1970. Synopsis of biological data on the eel Anguilla anguilla (Linnaeus) 1758. F.A.O. Fish. Synopses $\mathbf{8 0}$.

Eales, J. G., 1968. The eel fisheries of Eastern Canada. Bull. Fish. Res. Bd Can. 166, 1-79.

Frost, W. E., 1950. The eel fisheries of the River Bann, Northern Ireland, and observations on the age of silver eels. J. Cons. perm. int. Explor. Mer 16, 358-383.

Hildebrand, S. F. \& Schroeder, W. C., 1928. Fishes of Chesapeake Bay. Bull. U.S. Bur. Fish. $43(1), 1-366$.

JENs, G., 1952-53. Uber den lunaren Rhythmus der Blankaalwanderung. Arch. FischWiss. 4, 94-110.

Knöpp, Von H., 1952. Die Laichwanderung des Aales (Anguilla vulgaris) und ihre Beziehungen zu Mondstand und Wetter. Zool. Anz. 149, 169-177.

Lowe, R. H., 1952. The influence of light and other factors on the seaward migration of the silver eel (Anguilla anguilla L.). J. Anim. Ecol. 21, 275-309.

Rasmussen, C. J., 1951. Two Danish finds of female eels (Anguilla anguilla) in spawning or partial spawning dress. Rep. Dan. biol. Stn 53, 36-39.

Rıchкus, W. A., 1974. The influence of environmental variables on the migratory behavior of adult and juvenile alewives, Alosa pseudobarengus (WrLson). Thesis, Univ. Rhode Island, $225 \mathrm{pp}$.

- 1975. Factors influencing the seasonal and daily patterns of alewives (Alosa pseudoharengus) migration in a Rhode Island river. J. Fish. Res. Bd Can. 31, 1485-1497.

Smith, M. W. \& SAunders, J. W., 1955. The American eel in certain fresh waters of the Maritime Provinces of Canada. J. Fish. Res. Bd Can. 12, 238-269.

Svardson, G., 1949. Eels (Anguilla anguilla) found in Sweden in partial nuptial dress. Rep. Inst. Freshwat. Res. Drottningholm 29, 129-134.

Tesck, F.-W., 1973. Der Aal. Parey, Berlin, 306 pp.

Vladykov, V. D., 1966. Renmarks on the American eel (Anguilla rostrata, LESUeUR). Sizes of elvers entering streams; the relative abundance of adult males and females; and present economic importance of eels in North America. Verh. int. Ver. theor. angew. Limnol. 16, $1007-1017$.

- 1973. Macrophthalmia in the American eel (Anguilla rostrata). J. Fish. Res. Bd Can. 30, 689-693.

Wenner, C. A. \& Musick, J. A., 1974. Fecundity and gonad observations of the American eel, Anguilla rostrata, migrating from Chesapeake Bay, Virginia. J. Fish. Res. Bd Can. 31, 1387-1391.

Winn, H. E. \& Hammen, S., 1969. Migratory habits of the American eel pose problems for biologists. Maritimes 43, 3-5.

First author's address: Dr. H. E. WINN

Graduate School of Oceanography

University of Rhode Island

Kingston, Rhode Island 02881

USA 